05

\title{
Влияние отжига в газообразном цинке на люминесценцию в видимом и среднем ИК диапазонах $\mathrm{ZnSe}: \mathrm{Fe}^{2+}$
}

\author{
(C) А.В. Боряков ${ }^{1}$, А.А. Гладилин ${ }^{2}$, Н.Н. Ильичёв ${ }^{2}$, В.П. Калинушкин ${ }^{2}$, С.А. Миронов 2 , , Р.P. Резванов ${ }^{3}$, \\ О.В. Уваров ${ }^{2}$, В.П. Чегнов ${ }^{4}$, О.И. Чегнова ${ }^{4}$, М.В. Чукичев $^{5}$, А.А. Ширяев ${ }^{6}$ \\ ${ }^{1}$ Нижегородский государственный университет им. Н.И. Лобачевского, \\ 603950 Нижний Новгород, Россия \\ ${ }^{2}$ Институт общей фризики имени А.М. Прохорова РАН, \\ 119991 Москва, Россия \\ ${ }^{3}$ Национальный исследовательский ядерный университет „МИФИ“, \\ 115409 Москва, Россия \\ ${ }^{4}$ НИИ Материаловедения, \\ 124460 Зеленоград, Москва, Россия \\ ${ }^{5}$ Московский государственный университет им. М.В. Ломоносова, физический фракультет, \\ 119991 Москва, Россия \\ ${ }^{6}$ Нижегородский государственный технический университет им. Р.Е. Алексеева, \\ 603950 Нижний Новгород, Россия \\ ฯ e-mail.: sa.mironov@kapella.gpi
}

Поступило в Редакцию 2020 г.

В окончательной редакции 2020 г.

Принято к публикации 2020 г.

\begin{abstract}
Описаны результаты исследования влияния отжига в атмосфере цинка на примесно-дефектный состав легированных диффузией железа пластин $\mathrm{ZnSe}: \mathrm{Te}$ на характеристики катодолюминесценции (КЛ) ИК диапазона. Обнаружено образование преципитатов на границах двойников. Показано, что в структурах с поверхностной концентрацией железа больше 1 at.\% наблюдается существенный рост интенсивности КЛ в ИК диапазоне в результате отжига в цинковой атмосфере. Обнаружено частичное восстановление межзонной люминесценции в областях с высокой концентрацией железа в результате отжига.
\end{abstract}

Ключевые слова: $\mathrm{ZnSe}: \mathrm{Fe}, \mathrm{ZnSe}: \mathrm{Te}$, катодолюминесценция, рентгеновский флуоресцентый анализ, двухфотонная конфокальная микроскопия.

DOI: $10.21883 /$ OS.2020.11.50174.142-20

\section{Введение}

Кристаллы селенида цинка, легированные железом $(\mathrm{ZnSe}: \mathrm{Fe})$, используются в качестве активной среды перестраиваемых лазеров среднего ИК диапазона $3.6-5 \mu \mathrm{m}[1]$. К настоящему времени достигнуты рекордные генерационные характеристики $\mathrm{ZnSe}$ : Fe-лазеров при оптической накачке Er:YAG-лазерами и газоразрядными лазерами на фториде водорода [2-4]. Однако создание малогабаритной высокоэффективной лазерной системы с использованием таких методов накачки маловероятно. В последние годы идет поиск других путей создания инверсной населенности ионов железа - например, ударной ионизацией „горячими“ (с энергией несколько $\mathrm{keV}$ ) электронами (катодолюминесценция, КЛ). В работе [5] впервые были исследованы спектральные характеристики КЛ диффузионных структур $\mathrm{ZnSe}: \mathrm{Fe}$ в среднем ИК диапазоне $(3.6-4.4 \mu \mathrm{m})$ при облучении потоком электронов с энергией $40 \mathrm{keV}$. Показано, что спектр КЛ в этом диапазоне совпадает со спектром люминесценции при оптической накачке и обусловлен излучательным переходом между уровнями внутрицентровых состояний ${ }^{5} T_{2}$ и ${ }^{5} E$ ионов железа $\mathrm{Fe}^{2+}$.
В [6] сообщалось об исследовании влияния концентрации железа на характеристики КЛ структур ZnSe:Fe в среднем ИК диапазоне (ИККЛ) и было показано, что максимальная интенсивность КЛ наблюдается в структурах с концентрацией железа около 0.8 wt.\%. В paботе [7] сообщалось о влиянии отжига в газообразном цинке на люминесцентные характеристики монокристаллов $\mathrm{ZnSe}: \mathrm{Fe}$. В частности, сообщалось о частичном восстановлении межзонной люминесценции в областях этих кристаллов с высокой концентрацией железа.

Целью настоящей работы является исследование влияния отжига в атмосфере цинка на характеристики КЛИК диапазона и примесно-дефектный состав структур, полученных диффузией Fe в пластины $\mathrm{ZnSe}: \mathrm{Te}$, вырезанные из кристаллов, полученных методом Бриджмена при высоком давлении инертного газа.

\section{Методика эксперимента и полученные результаты}

Эксперименты в настоящей работе проводились на пластинах $\mathrm{ZnSe}: \mathrm{Te}$, легированных железом методом 
термодиффузии при температуре $950^{\circ} \mathrm{C}$. Исходные пластины, в которые проводилась диффузия Fе, были вырезаны из слитков, выращенных из расплава методом Бриджмена в графитовых тиглях под давлением высокочистого аргона $100 \mathrm{~atm}$. Легирование теллуром проводилось в процессе роста кристаллов. Концентрация теллура составляла примерно $0.1 \mathrm{wt} . \%$. Большой размер атомов Те „разрыхляет“ кристаллическую решетку $\mathrm{ZnSe}$, способствуя диффузии примеси Fe. Материалом загрузки являлся CVD-ZnSe с содержанием 99.9996 wt.\% ZnSe, что, как показал анализ методом масс-спектрометрии с индуктивно- связанной плазмой [8], обеспечивало получение слитка с 99.9992 wt.\% ZnSe. Средняя поверхностная концентрация $\mathrm{Fe}$ в диффузионных структурах $\mathrm{ZnSe}: \mathrm{Fe}$ определялась рентгенофлуоресцентным методом (РФлА) в пятне диаметром $1.5 \mathrm{~mm}$ с помощью спектрометра Мистраль М-1 фирмы Bruker. Предел обнаружения примесей составлял $0.01 \mathrm{wt} . \%$. Определение пространственного распределения примесей в объеме диффузионных структур проводилось с помощью электронной сканирующей микроскопии (СЭМ) на растровом электронном микроскопе JSM-IT300LV (JEOL) методом энергодисперсионного рентгеновского микроанализа с применением энергодисперсионного детектоpa X-Max ${ }^{\mathrm{N}} 20$ (OxfordInstruments). Электронно-микроскопические изображения были получены в режиме регистрации низкоэнергетичных вторичных электронов, ускоряющее напряжение составляло $20 \mathrm{kV}$, ток электронного пучка $0.5 \mathrm{nA}$. Состав рассчитывался по методу фундаментальных параметров, предел обнаружения элементов составлял от 0.05 at.\%. С помощью рентгеновского микроанализа (РМА) анализировалось пространственное распределение железа в объеме кристаллов $\mathrm{ZnSe}: \mathrm{Fe}$, что позволило выделить часть железа, не перешедшего в преципитаты.

Примесно-дефектный состав диффузионных структур и исходных пластин исследовался методом двухфотонной конфокальной микроскопии (ДФКМ) с помощью микроскопа Carl Zeiss LSM NLO 710. ДФКМ позволяет регистрировать пространственное распределение межзонной люминесценции и примесно-дефектных центров (ПДЦ), люминесцирующих в диапазоне $0.48-073 \mu \mathrm{m}$, и регистрировать рекомбинационно-активные дефекты структуры (границы зерен, двойники и т.д.). Подробно методика описана в $[8,9]$. Эксперименты проводились при комнатной температуре. КЛ возбуждали импульсной электронной пушкой при энергии ускоренных электронов $36 \mathrm{keV}$; средняя глубина проникновения электронов в образец составляла $\approx 4 \mu \mathrm{m}$. Облучение электронами и наблюдение люминесценции производились под углом $45^{\circ}$ к поверхности образца. Излучение КЛ выводилось из камеры через окно из $\mathrm{CaF}_{2}$ и фокусировалось коллиматором из двух линз на входное окно приемника PDMM42NB чувствительностью в интервале $2.9-5.2 \mu \mathrm{m}$ (ООО „ИОФФЕЛЕД“). Таким образом, регистрировалось все излучение в этом спектральном диапазоне. Регистрация формы и интенсивно-

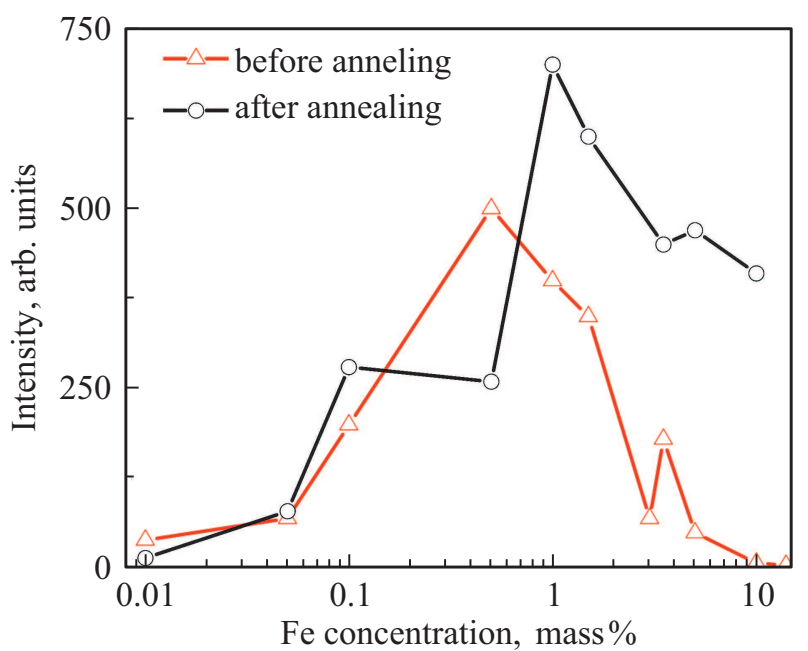

Рис. 1. Зависимость интенсивности ИККЛ от концентрации железа для отожженных и неотожженных образцов.

сти сигнала КЛ производилась с помощью осциллографа марки TektronixTDS-2014B. Эксперименты проводились при комнатной температуре и при температуре жидкого азота. Подробно методика этих экспериментов приведена в $[5,6]$.

Для определения влияния концентрации $\mathrm{Fe}$ на интенсивность КЛ и кинетику ее спада из центральной области пластины $\mathrm{ZnSe}$ толщиной $2.0 \mathrm{~mm}$ с поверхностной концентрацией $\mathrm{Fe}$, равной $14 \mathrm{wt} . \%$, были вырезаны 12 соседних образцов размером $5 \times 5 \mathrm{~mm}$. Толщина слоя, обогащенного $\mathrm{Fe}$ (до концентрации менее $0.01 \mathrm{wt} . \%$ ), составляла $150 \mu \mathrm{m}$. Удаляя механическим шлифованием с поверхности разное количество материала, из этих образцов была приготовлена серия образцов с разным содержанием $\mathrm{Fe}$ (в дальнейшем группа 1 кристаллов). Удаление материала проводилось с периодическим контролем концентрации $\mathrm{Fe}$ по поверхности образцов так, чтобы стандартное отклонение пяти измерений концентрации (в центре квадратного образца и по его четырем углам) не превышало 0.05 . После механической обработки поверхность изучаемых образцов только отмывалась, а дополнительной химической обработке не подвергалась, чтобы стехиометрия в приповерхностной области у образцов с разным содержанием Fе по возможности сохранялась. После проведения исследований образцы отмывались и подвергались отжигу в атмосфере цинка в квазизамкнутой системе при температуре $950^{\circ} \mathrm{C}$ в течение 24 h (группа 2 кристаллов). Все образцы отжигались одновременно в одинаковых условиях. После отжига проводилось повторное определение поверхностной концентрации железа в образцах с помощью РФлА. При отжиге происходила дополнительная диффузия примеси в объем кристалла, и измеряемая с помощью РФлА концентрация $\mathrm{Fe}$ несколько уменьшалась. 


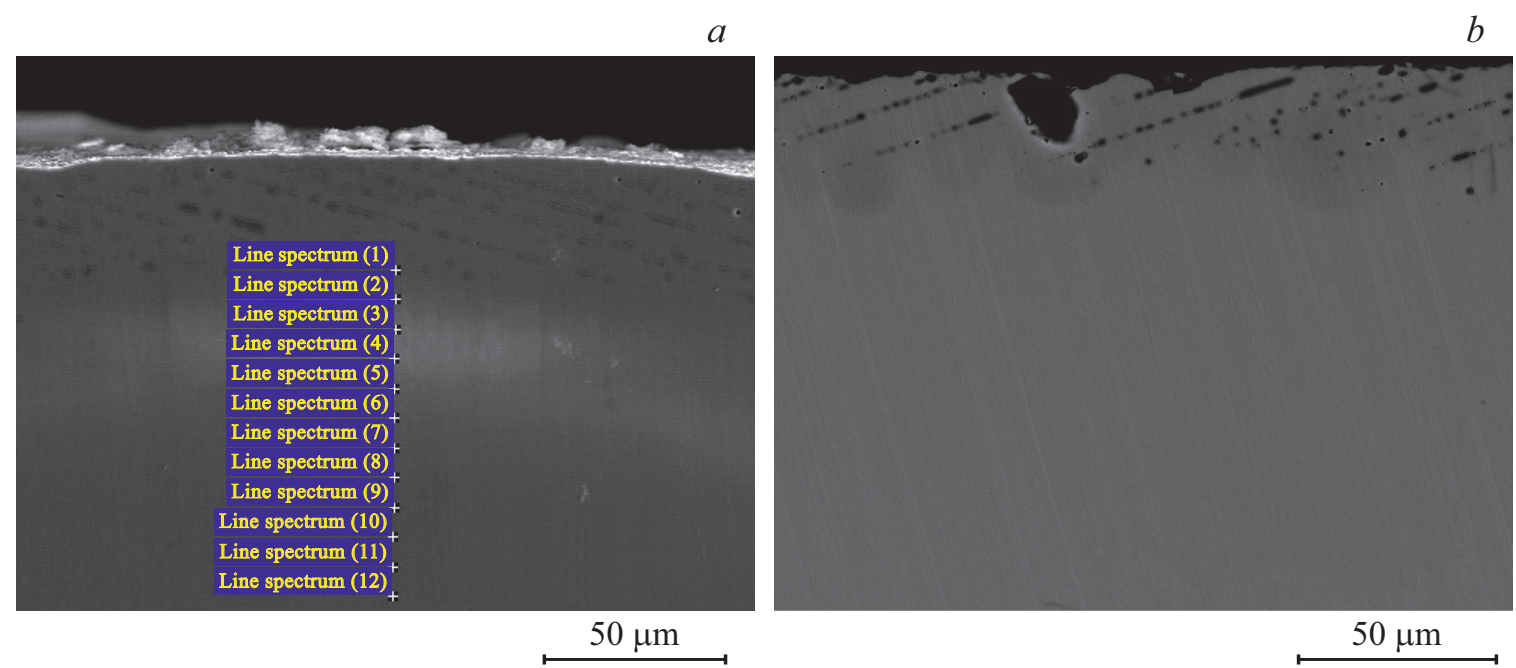

Рис. 2. СЭМ-изображения торцов образцов. (а) изображение образца № 1, полученное в режиме вторичных электронов; (b) изображение образца № 2, полученное в режиме отраженных электронов.

\section{Результаты и обсуждение}

На рис. 1 приведены зависимости интенсивности ИККЛ от концентрации железа, определенной с помощью РФлА для образцов группы 1 и 2 . Видно, что интенсивность ИККЛ для структур группы 1 немонотонно растет вплоть до концентраций железа примерно $0.8 \mathrm{wt} \%$, а потом начинает падать. Отжиг в цинке существенно увеличивает интенсивность ИККЛ при концентрациях железа более $1 \mathrm{wt} . \%$. В работе [6] уменьшение интенсивности ИККЛ при концентрациях железа больше $0.8 \mathrm{wt.} \%$ связывалось с возможным ухудшением структуры кристаллов с таким высоким содержанием примесей. Соответственно первой гипотезой, объясняющей увеличение интенсивности ИККЛ после отжига в цинке, было предположение о качественном улучшении дефектной структуры образцов.

На рис. $2, a, b$ приведены снятые с помощью сканирующей СЭМ в режиме вторичных (рис. $2, a$ ) и отраженных (рис. $2, b$ ) электронов картины торцов структуры группы 1 с концентрацией железа, определенной с помощью РФлА, 14 wt.\% (образец № 1) и той же структуры, но после отжига в цинке (образец № 2). Концентрация железа в нем уменьшилась и стала порядка $10 \mathrm{wt} . \%$.

Эти образцы могут рассматриваться (в силу способа формирования исследуемых групп кристаллов) как характеризующие свойства всей группы. В случае группы 1 это очевидно. Действительно, все образцы этой группы были получены путем механического шлифования поверхности образца перпендикулярно его торцу. В случае группы 2 в силу того, что образцы с разной поверхностной концентрацией железа отжигались в цинке индивидуально, возможно, это утверждение не совсем верно. Действительно, область кристалла с концентрацией железа, например, в 1 wt.\% в случае образца № 2 находилась на расстоянии от поверхности примерно
Данные РМА для областей вне и в преципитатах (рис. 4)

\begin{tabular}{l|c|c|c|c|c}
\hline Spectrum & C, \% & Fe, \% & Zn, \% & Se, \% & Total, \% \\
\hline SumSpectrum & 2.34 & 6.22 & 40.55 & 50.89 & 100.00 \\
Spectrum 3 & 1.63 & 92.09 & 3.41 & 2.87 & 100.00 \\
Spectrum 4 & 2.59 & 72.25 & 10.38 & 14.78 & 100.00 \\
Spectrum 5 & 2.26 & 1.20 & 42.95 & 53.58 & 100.00 \\
Spectrum 6 & 2.45 & 1.35 & 42.74 & 53.45 & 100.00 \\
Spectrum 7 & 2.76 & 1.32 & 42.52 & 53.39 & 100.00
\end{tabular}

$100 \mu \mathrm{m}$, а сам образец из концентрационной серии с такой концентрацией непосредственно контактировал с цинком. Однако выборочные эксперименты с образцами 1 группы с концентрацией железа, определяемой с помощью РФА 3 и 0.1 wt.\% и второй группы с концентрацией железа 1 и 1.5 wt.\% подтвердили предположение о возможности использования кристаллов № 1 и № 2 как характеризующих свойства всех кристаллов указанных выше групп.

На рис. $2, a, b$ хорошо видны границы двойников, декорированных преципитатами. При этом картины отожженных и не отожженных кристаллов практически не отличаются.

На рис. 3 приведена зависимость концентрации железа от расстояния от поверхности, с которой шло легирование образца № 1, полученная с помощью РМА. На рис. 4 приведена картина части торца образца из группы № 1 в режиме отраженных электронов с большим разрешением, а в таблице приведены данные РМА для области вне и внутри наблюдаемых преципитатов. Видно, что области образца с аномально большой концентрацией железа - это области в преципитатах. Аналогичные результаты получены и для образцов группы 2. Видно, что концентрация железа в части кристаллов вне области преципитатов, измеряемая с помощью РМА, 


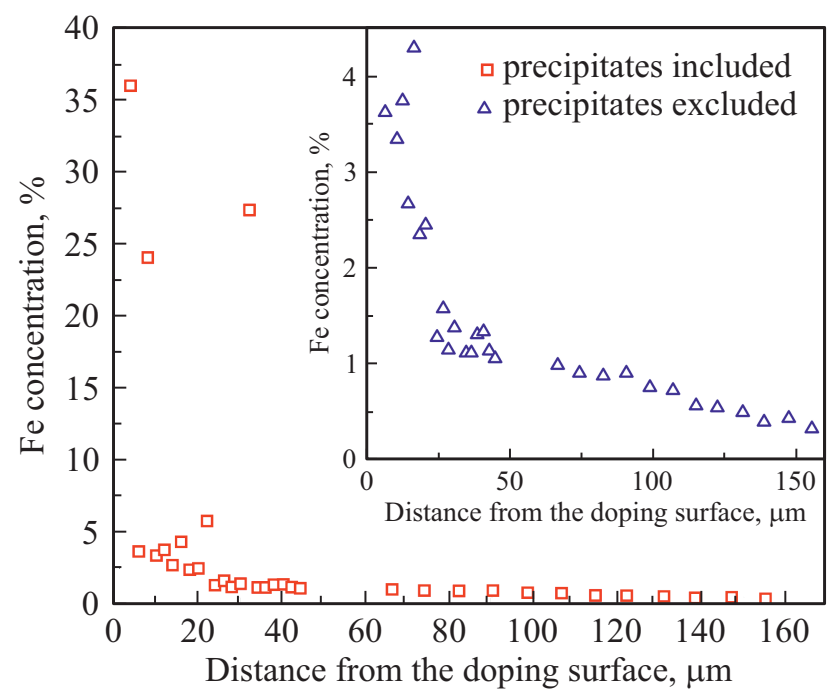

Рис. 3. Зависимость концентрации железа от расстояния от поверхности образцов группы 1 . Во вставке исключены точки, соответствующие прецепитатам.

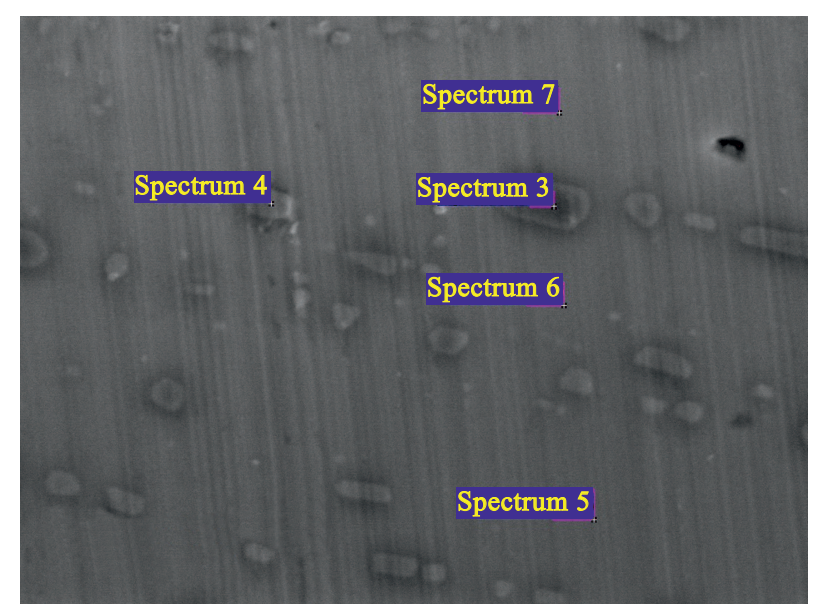

$10 \mu \mathrm{m}$

Рис. 4. Картина части торца образца из группы № 1 в режиме отраженных электронов (таблица).

существенно меньше измеряемой методом РФА интегральной концентрации железа. Так, например, в случае образца группы 1 с концентрацией железа по РФлА 3 wt.\% по данным РМА она составляла 0.7-0.8 wt.\%, а в образцах 2-й группы с концентрацией железа по РФлА 1 wt.\% была на уровне чувствительности РМА. Высокие же значения концентрации железа, полученные с полученные с помощью РФлА, обусловлены образованием преципитатов железа, которые, естественно, не приводят к образованию ионов двухвалентного железа в решетке кристалла.

На рис. 5 приведены плоские карты люминесценции на длинах волн 473 и $580 \mathrm{~nm}$ и спектры люминесценции в диапазоне 440-725 nm нелегированного железом, но легированного теллуром исходного кристалла $\mathrm{ZnSe}$.
Видно, что в кристалле есть дефекты неясной природы, но люминесцентные характеристики вне этих дефектов более-менее однородны и состоят из экситонной линии люминесценции с длиной волны $473 \mathrm{~nm}$, широкой полосы с максимумом в районе $580 \mathrm{~nm}$ и особенностями в спектре (возможно, в результате наложения двух линий) в районе $630 \mathrm{~nm}$. Эта линия похожа на линии, которые в работах $[10,11]$ связывались с люминесценцией теллура. В дальнейшем будем также ассоциировать эту линию с теллуром.

На рис. $6, a, b$ и 7, $a, b$ приведены плоские карты люминесценции на длине волны $473 \mathrm{~nm}$ образцов № 1 и № 2 и их спектры люминесценции в разных областях кристаллов. В областях, удаленных от поверхности, с которой шло легирование на расстояние более $100 \mu \mathrm{m}$ (т.е. там, где концентрация железа была невелика), спектры люминесценции и кристалла № 1, и кристалла № 2 похожи на спектр люминесценции нелегированного железом кристалла - наблюдается экситонная линия люминесценции и линия (линии) люминесценции, связанная (связанные) с теллуром. Области кристаллов, еще более удаленные от поверхности, с которой шло легирование, имели сходные спектры люминесценции. Различие в спектрах люминесценции в кристаллах № 1 и № 2 состоит в несколько большей интенсивности люминесценции экситона в кристалле № 2.

Рассмотрим теперь люминесцентные характеристики этих кристаллов в областях с высокой концентрацией железа, т.е. тех частей кристаллов, в которых и регистрировалась ИККЛ.

В областях кристалла в образце № 1, находящихся на расстоянии примерно $30 \mu \mathrm{m}$ от поверхности, с которой шло легирование (это зона регистрируемых преципитатов и концентрации по РФлА примерно до 1-2wt.\%), люминесценция отсутствует во всем исследуемом диапазоне. Эта область не визуализируется с помощью ДФКМ. В отожженном кристалле в этой области наблюдается экситонная люминесценция и люминесценция в районе 715-725 nm. Эти линии наблюдались ранее [7,9] и идентифицировались как „красные“ линии. Также хорошо видны нелюминесцирующие двойниковые границы и преципитаты. Люминесценция наблюдается в областях, свободных от двойников и преципитатов. При увеличении расстояния от поверхности легирования в образце № 1 начинает появляться экситонная линия люминесценции, которая растет. На расстояниях больше $30-40 \mu \mathrm{m}$ от поверхности, с которой шло легирование, появляется также широкая линия. Максимум интенсивности этой линии в этой части образца лежит в области $520 \mathrm{~nm}$. По мере удаления от поверхности происходит смещение максимума интенсивности в область больших длин волн. Такие спектры наблюдались в $[9,12]$ в кристаллах, легированных железом, и связывались c рекомбинацией неравновесных носителей через так называемые зеленые дефекты. В этих работах предполагалось, что эти дефекты входят в кристаллы в процессе их легирования железом. Проявляются также красные 


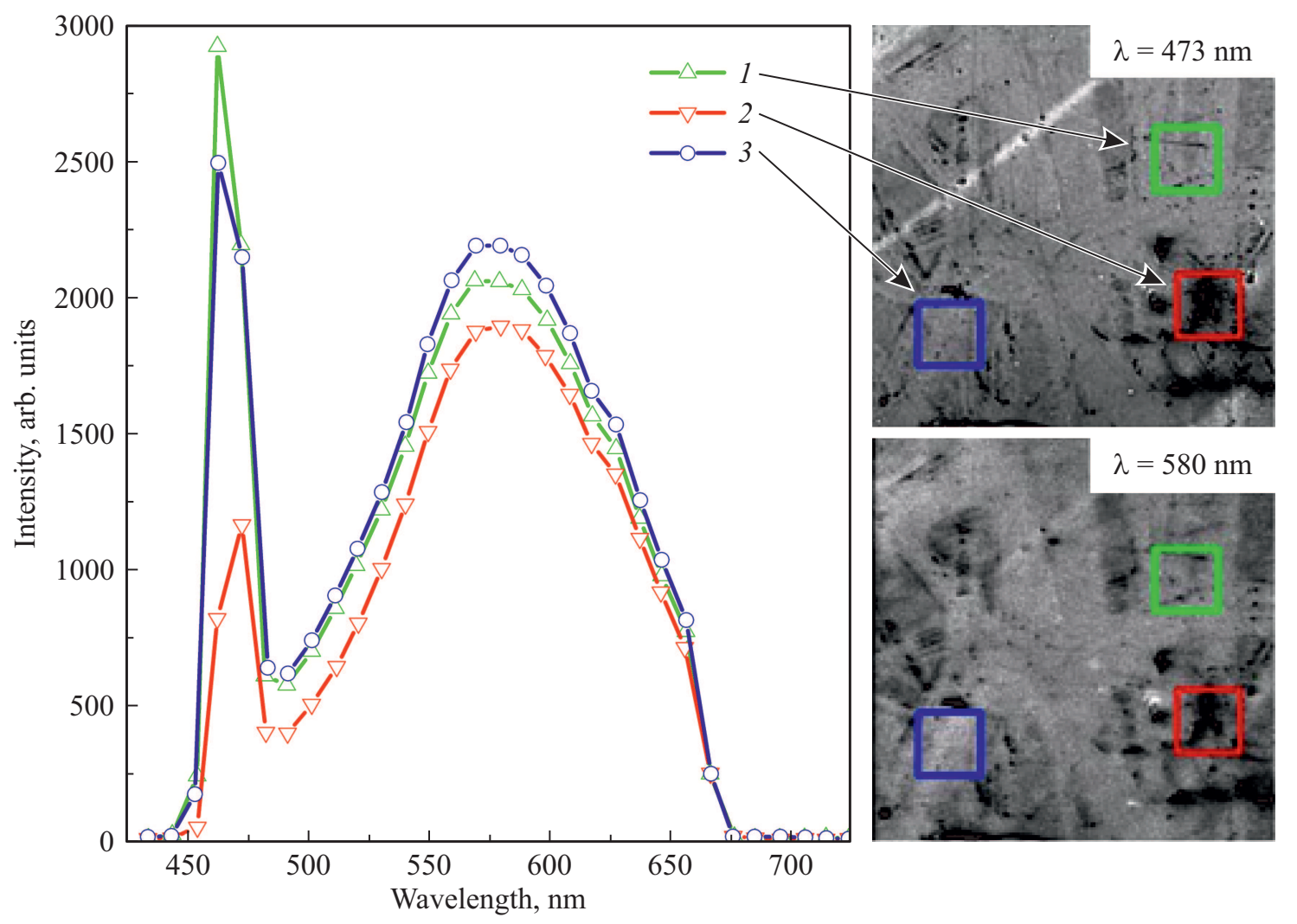

Рис. 5. Спектры люминесценции и плоские карты люминесценции кристаллов $\mathrm{ZnSe}$ :Te.

линии. Визуализация кристалла № 1 с помощью ДФКМ происходит только в зоне, расположенной от поверхности дальше $50 \mu \mathrm{m}$, в которой отсутствуют выявляемые РМА преципитаты. В дальнейшем интенсивности экситонной и „примесной“ линий начинают расти и переходят в спектр для нелегированной зоны.

В случае кристалла № 2 практически во всей зоне области 50-70 $\mu \mathrm{m}$ от поверхности легирования спектр люминесценции не меняется и состоит из экситонной линии и слабых красных линий. Это зона концентраций железа по РФА примерно до 1-2 wt.\%. Затем происходит резкий рост экситонной и примесной люминесценции, который быстро переходит в спектр нелегированной области.

\section{Обсуждение результатов}

Полученные результаты позволяют утверждать следующее.

1. Значительная часть железа в исследуемых кристаллах находится в форме преципитатов. Концентрация железа, растворенного в решетке $\mathrm{ZnSe}$, меньше в тричетыре раза и не превосходит 3-4 wt.\%. В структурах с концентрацией железа, большей 5 wt.\%, определяемой с помощью РФА, образуются колонии преципитатов, которые декорируют границы двойников.
2. Отжиг в цинке не приводит к качественному улучшению структуры сильнолегированных областей кристаллов.

3. В результате отжига в цинке в зоне с максимальной концентрацией железа происходит частичное восстановление экситонной люминесценции. Кроме того, обнаружено практическое отсутствие в этой зоне какойлибо люминесценции, связанной с примесно-дефектными центрами. Такая люминесценция наблюдается в аналогичной зоне образца № 1.

Эти результаты позволяют предположить, что спад интенсивности ИККЛ при увеличении концентрации железа связан в первую очередь не с образованием колоний преципитатов, а с наличием в этих областях кристаллов большого числа примесно-дефектных центров (например, „зеленых“ ПДЦ). В [10,11] предполагалось, что эти дефекты образуются либо на поверхности, с которой идет легирование, либо в области, непосредственно к ней прилегающей, и в дальнейшем диффундируют вглубь образца. Эти ПДЦ являются конкурирующими с ионами железа центрами взаимодействия как с первичными электронами, так и с генерируемыми либо ими, либо другими источниками неравновесных носителей тока. Отжиг в цинке очищает эту зону от этих центров, что приводит как к увеличению интенсивности ИККЛ, так и частичному восстановлению экситонной люминесценции при двухфотонном возбуждении носителей тока. 

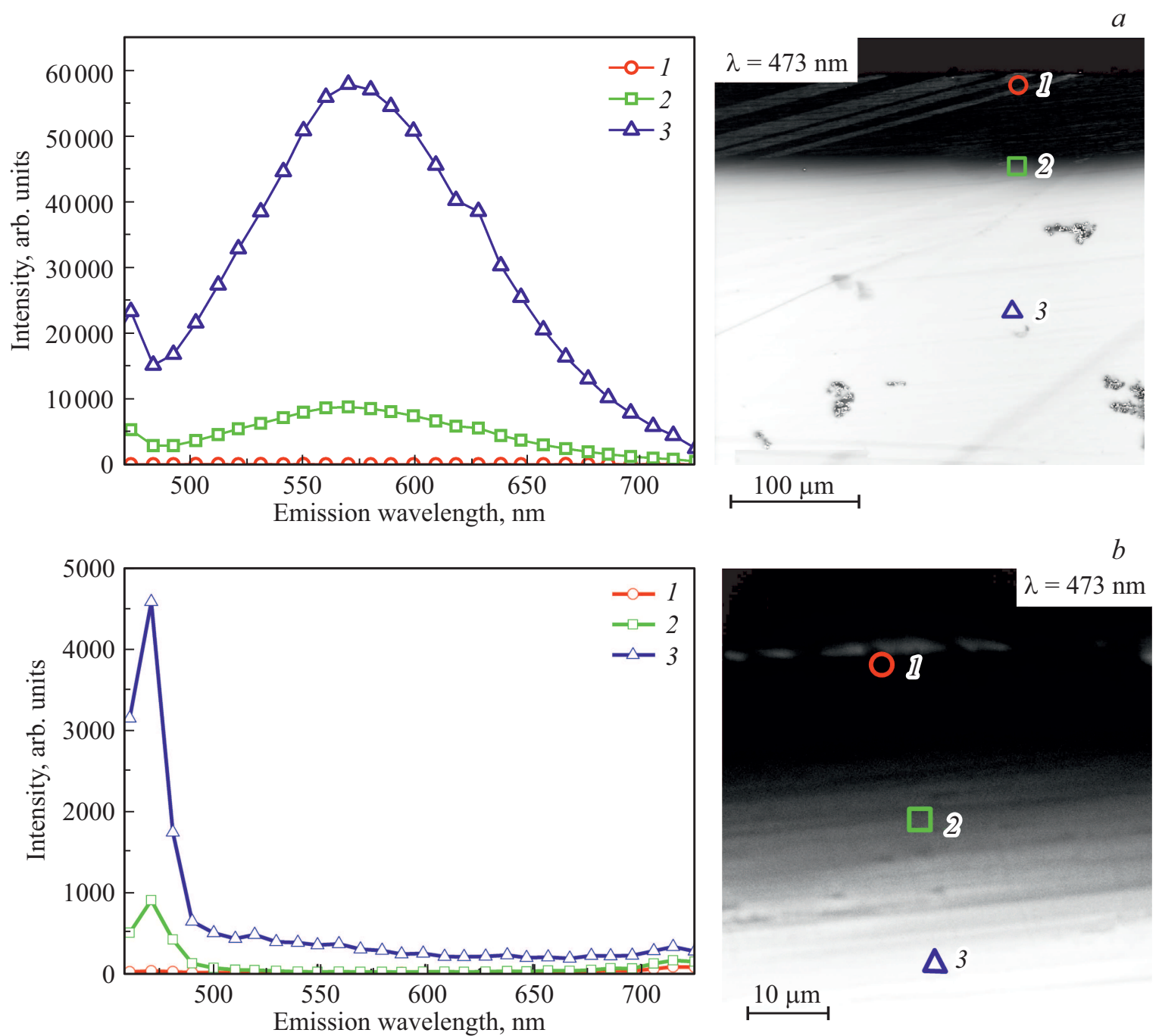

Рис. 6. Спектры люминесценции и плоская карта люминесценции на длине волны $473 \mathrm{~nm}$ образца из группы № 1 : (a) удаленные от поверхности легирования области, $(b)$ приповерхностная область.

По-видимому, концентрация этих ПДЦ велика в зоне, примыкающей к поверхности, откуда идет легирование. Возможно, именно эта область, а не поверхность кристалла является местом их зарождения. При увеличении расстояния от поверхности концентрация этих ПДЦ и соответственно их влияние на процессы взаимодействия неравновесных носителей тока с железом быстро падает. Поэтому эффективность отжига в цинке уменьшается, и он слабо влияет на интенсивность ИККЛ.

Таким образом, одним из основных направлений работы по получению кристаллов $\mathrm{ZnSe}: \mathrm{Fe}$, наиболее подходящих для создания инверсной населенности ионов железа с помощью их возбуждения горячими носителями тока, становится очистка рабочей зоны кристаллов от посторонних ПДЦ.

Работа выполнена с использованием оборудования центра коллективного пользования „Технологический и диагностический центр для производства, исследования и аттестации микро- и наноструктур“ Института общей физики им. А.М. Прохорова РАН в рамках программы РАН „Перспективные физико-химические технологии специального назначения“.

\section{Финансирование работы}

Финансовая поддержка работы осуществлялась грантом РФФИ 18-29-20048 „Исследование возможности создания высокоэффективных лазеров ИК диапазона (4-5 $\mu \mathrm{m})$ на основе кристаллов $\mathrm{ZnSe}$, легированных железом, при формировании инверсной населенности в ионах активатора путем ударного возбуждения горячими электронами“.

\section{Конфликт интересов}

Авторы заявляют, что у них нет конфликта интересов. 

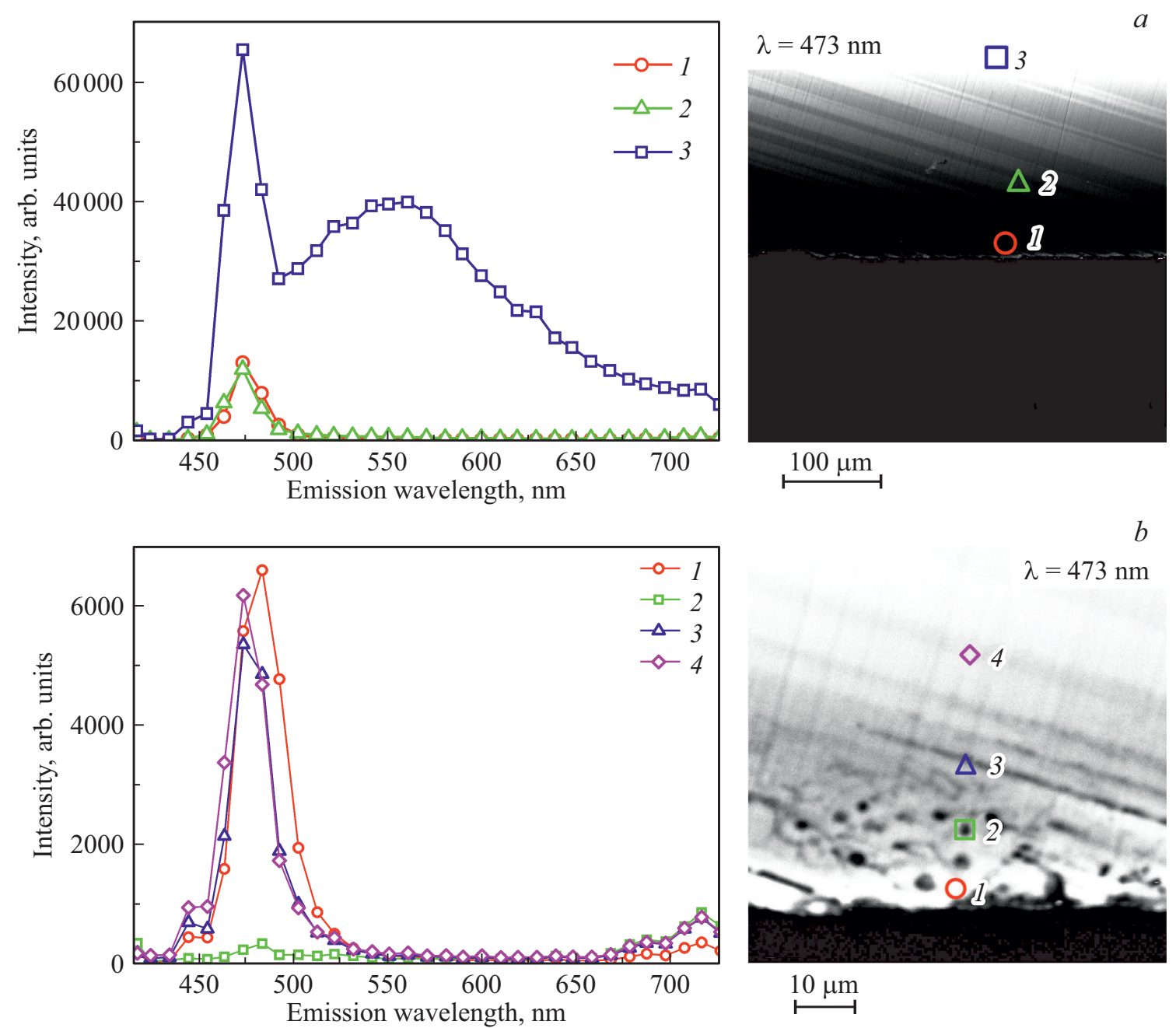

Рис. 7. Спектры люминесценции и плоская карта люминесценции на длине волны $473 \mathrm{~nm}$ образца из группы № 2: (a) удаленные от поверхности легирования области, $(b)$ приповерхностная область.

\section{Список литературы}

[1] Fedorov V.V., Mirov S.B., Gallian A., Badikov D.V., Frolov M.P., Korostelin Y.V., Kozlovsky V.I., Landman A.I., Podmar'kov Y.P., Akimov V.A., Voronov A.A. // IEEE J. Quantum Electronics. 2006. V. 42. N 9. P. 907.

[2] Martyshkin D.V., Fedorov D.V., Mirov M., Moskalev I., Vasilyev S., Mirov S.B. // 2015 CLEO: OSA Technical Digest SF1F.2.

[3] Gavrishchuk E.M., Ikonnikov V.B., Kazantsev S.Yu., Kononov I.G., Rodin S.A., Savin D.V., Timofeeva N.A., Firsov K.N. // Quantum Electronics. 2015. V. 4. N 9. P. 823-827.

[4] Kozlovsky V.I., Korostelin Y.V., Podmar'kov Y.P., Skasyrsky Y.K., Frolov M.P. // J. Phys.: Conf. Ser. 2016. V. 740. P. 012006.

[5] Gladilin A.A., Gulyamova E.S., Danilov V.P., Il?ichev N.N., Kalinushkin V.P., Odin I.N., Pashinin P.P., Rezvanov R.R., Sidorin A.V., Studenikin M.I., Chapnin V.A., Chukichev M.V. // Quantum Electronics. 2016. V. 46. N 6. P. 545-547.

[6] Чукичев М.В., Чегнов В.П., Резванов Р.Р., Чегнова О.И., Калинушкин В.П., Гладилин А.А. // ОПт. и спектр. 2019. T. 126. B. 202. C. $122-125$.
[7] Калинушкин В.П., Клечковская В.В., Клевков Ю.В., Чукичев М.В., Резванов Р.Р., Ильичев Н.Н., Орехов А.С., Уваров О.В., Миронов С.А., Гладилин А.А., Чапнин В.А. // Кристаллография. 2019. Т. 64. № 1. С. 111-116.

[8] Kalinushkin V.P., Uvarov O.V., Gladilin A.A. // J. Electronic Materials. 2018. V. 47. N 9. P. 5087-5091. doi 10.1007/s11664-018-6393-4

[9] Гладилин А.А., Ильччев Н.Н., Калинушкин В.П., Студеникин М.И., Уваров О.В., Чапнин В.А., Туморин В.В., Новиков Г.Г. // ФТП. 2019. Т. 53. В. 1. С. 5-12.

[10] Baltramiejunas R., Ryzhikov V.D., Gavryushin V., Kazlauskas A., Raciukaitis G., Silin V.I., Juodzbalis D., Stepankevicius V. // J. Lumin. 1992. V. 52. P. 71-81.

[11] Морозова Н.К., Назарова Л.Д., Каретников И.А., Галстян В.Г., Гальчинечкий Л.П., Рыжиков В.Д., Голованова O.P. // ФТП. 1995. Т. 29. В. 9. С. 1.

[12] Балабанов С.С., Гаврищук Е.М., Гладилин А.А., Иконников В.Б., Ильичев Н.Н., Калинушкин В.П., Миронов С.А., Савин Д.В., Студеникин М.И., Тимофеева Н.А., Уваров О.В., Чапнин В.А. // Неорганические материалы. 2019. T. 55. № 5. C. $459-468$. 